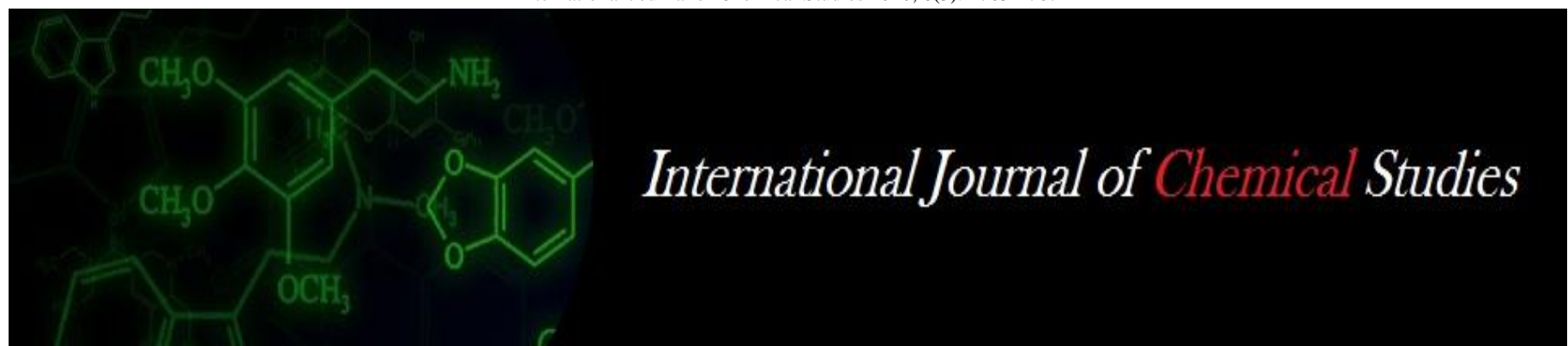

P-ISSN: 2349-8528

E-ISSN: 2321-4902

www.chemijournal.com

IJCS 2020; 8(3): 2763-2767

(C) 2020 IJCS

Received: 25-03-2020

Accepted: 27-04-2020

Bishnupada Giri

Ph.D. Scholar, Department of

Floriculture and Landscaping,

College of Agriculture OUAT,

Bhubaneswar, Odisha, India

Sashikala Beura

Professor and Head, Departmen of Floriculture and Landscaping, College of Agriculture OUAT, Bhubaneswar, Odisha, India
Corresponding Author: Sashikala Beura

Professor and Head, Department of Floriculture and Landscaping, College of Agriculture OUAT, Bhubaneswar, Odisha, India

\section{Effect of plant bio-regulators on vegetative growth and flowering of gerbera (Gerbera jamesonii B.) cv. Goliath in open field condition}

\author{
Bishnupada Giri and Sashikala Beura
}

DOI: https://doi.org/10.22271/chemi.2020.v8.i3an.9630

\begin{abstract}
The present investigation entitled "Impact of Plant Bio-regulator on growth and flowering of gerbera (Gerbera jamesonii B.) cv. Goliath" was carried out in premises of Bio-technology cum Tissue Culture Centre, Odisha University of Agriculture and Technology, Bhubaneswar during 2015-16 and 2016-17. The objective of the study was to standardize suitable bio-regulators on flower production in gerbera in open field condition. Apart from control eight treatments of growth regulators were used like $\mathrm{GA}_{3} @ 100$ ppm, and 150 ppm; Cycocel @ 700 ppm and 800 ppm with or without amino acids as foliar spray. Among vegetative parameters maximum plant spread, leaf length, petiole length, leaf width and leaf area was found in $\mathrm{GA}_{3} @ 150 \mathrm{ppm}+$ Amino Acid while maximum leaf number/plant, number of suckers/plant and chlorophyll content in leaf was found in treatment with cycocel @ 700 ppm+ Amino acid. In flowering parameters maximum number of flowers $/ \mathrm{plant} / \mathrm{m}^{2}$ in a year was found in treatment with cycocel @ 700 ppm + Amino acid.
\end{abstract}

Keywords: Gibberellin, cycocel, amino acid

\section{Introduction}

Gerbera (Gerbera jamesonii B.) also known as Transvaal daisy, Barbeton daisy or African daisy belonging to family Asteraceae occupies $5^{\text {th }}$ place as cut flower in international flower trade (Sujatha et al. 2002) ${ }^{[20]}$. It is popular because of it's attractive colour, long vase life and suitability for long distant transport (Bose et al. 2003 and Chauhan, 2005) ${ }^{[1,4]}$. It is used for fresh and dry flower arrangement, exhibition, decoration, bouquet preparation (Patra et al., 2015) ${ }^{[17]}$. Local and improved cultivar are grown in garden, flower bed, pots, borders, dish garden and rock garden. Flowers are of different colour like white cream, yellow, pink, orange, brick red, scarlet, salmon, maroon and bicolor and are available in single, semi-double or double form. Application of plant Bio-regulators at specific concentration modify growth, flowering, flower yield and post-harvest quality of flowers. Growth promoters like Auxin, Gibberellin and Cytokinin modify physiological process by accelerating plant growth while growth retardant like cycocel and Abscisic acid inhibit plant growth. Maximum vegetative growth, flower yield and quality was observed in gerbera by application of $\mathrm{GA}_{3} @ 150$ ppm. (Dalal et al. 2009) ${ }^{[5]}$. Similarly, application of growth retardant like paclobutrazole @ 25 to $100 \mathrm{ppm}$ in gerbera reduce plant spread, increase leaf number/plant, increase chlorophyll content, decrease in stalk length, increase in stalk thickness, number of flowers and flower quality parameters. (Bekheta et al. 2008) ${ }^{[2]}$.

\section{Materials and Method}

The present study was conducted in premises of Bio-technology cum Tissue Culture Centre, Odisha University of Agriculture Technology, Bhubaneswar from Nov. to Oct. 2015-16 and 2016-17 in open condition. The experimental site was situated $63 \mathrm{~km}$ away from Bay of Bengal at an altitude of $25 \mathrm{~m}$ above MSL and extended between $20^{\circ} 15^{\prime}$ North latitude and $85^{\circ}$ 50 ' East longitude. The average rainfall of the site was $1646 \mathrm{~mm}$. The maximum temperature during the experimental period was $38.8{ }^{\circ} \mathrm{C}$ to $40.8{ }^{\circ} \mathrm{C}$ and minimum temperature was $14.1^{\circ} \mathrm{C}$ to $15.2^{\circ} \mathrm{C}$. The relative humidity during the experimental period was $37 \%$ to $94 \%$. The experimental soil was sandy loam with $\mathrm{pH}$ 5.83, EC $0.64 \mathrm{ds} / \mathrm{m}$, OC $0.475 \%$; N $125 \mathrm{~kg} / \mathrm{ha}$, 
$\mathrm{P}_{2} \mathrm{O}_{5} 67.1 \mathrm{~kg} / \mathrm{ha}, \mathrm{K}_{2} \mathrm{O} 166.6 \mathrm{~kg} / \mathrm{ha}$. The growing media was composed of soil, FYM and coco peat in 1: 1: 1 proportion. Earthen pot with a hole at the bottom were used for planting. The pot were filled with soil mixture. Four leaved tissue culture plantlet of gerbera cv. Goliath a variety suitable for protected cultivation were used for planting in open field condition. A basal dose of NPK @ 10: 15:20 g per $\mathrm{m}^{2}$ was applied. The experiment was laid down in Completely Randomized Design (CRD) with nine treatments and three replication per treatments. There were 10 plants per replication and 30 plants per treatment making a total population of 270 plants. The present experiment comprised with 9 treatments i.e. $\mathrm{T}_{1}$ (Control), $\mathrm{T}_{2}\left(\mathrm{GA}_{3} @ 100\right.$ ppm), $\mathrm{T}_{3}\left(\mathrm{GA}_{3} @ 150\right.$ ppm), $\mathrm{T}_{4}$ (Cycocel @700 ppm), T5 (Cycocel @ 800 ppm), $\mathrm{T}_{6}\left(\mathrm{GA}_{3} @ 100 \mathrm{ppm}+\right.$ Amino Acid @ $\left.2 \mathrm{ml} / \mathrm{l}\right)$, $\mathrm{T}_{7}\left(\mathrm{GA}_{3} @ 150\right.$ ppm + Amino Acid @ 2 ml/l), T (Cycocel @ 700 ppm + Amino Acid @ 2 ml/1), T9 (Cycocel @ 800 ppm + Amino Acid @ 2 ml/l)

For application of treatments to the plants following concentrations of plant bio regulators solution were prepared. With help of precision balance $100 \mathrm{mg}$ and $150 \mathrm{mg}$ of $\mathrm{GA}_{3}$ were measured and taken in two beakers separately. Little quantity of sodium hydroxide was added to the beaker for easy solubility. Then the volume was made to 1 liter by adding water in to the beaker thus preparing $100 \mathrm{ppm}$ and 150 ppm of $\mathrm{GA}_{3}$ solution. Similarly, $700 \mathrm{mg}$ and $800 \mathrm{mg}$ of cycocel were measured and taken in two beakers separately. Little quantity of alcohol was added to the beaker for easy solubility and then the volume was made to 1 liter by adding water into the beaker. Thus, $700 \mathrm{ppm}$ and $800 \mathrm{ppm}$ cycocel solution were prepared.

The observation were recorded from 5 randomly selected plant within each replication of treatment for different vegetative parameter like plant spread, number of leaves, leaf length, leaf width, length of petiole, number of suckers/plant, chlorophyll content and floral parameters like number of flower/plant. The data collected were analyzed statistically following the method of Gomez and Gomez (1984) ${ }^{[9]}$ using one way ANOVA in CRD. A comparison of treatment means were done at $5 \%$ level of significance $(\mathrm{P}=0.05)$.

\section{Results and Discussion}

The result of the experiment obtained in the year 2015-16 to 2016-17 were pooled and presented under following headings.

\section{(A) Effect of PBR application on Vegetative parameters 1. Plant Spread}

Pooled data from both the years revealed that in winter season maximum plant spread $(69.82 \mathrm{~cm})$ was found in $T_{7}$ receiving GA @ 150 ppm+ Amino Acid which was closely followed by $\mathrm{T}_{6}$ (GA @ $100 \mathrm{ppm}+$ Amino Acid). The minimum plant spread $(56.81 \mathrm{~cm})$ was recorded in $\mathrm{T}_{5}$ (Cycocel @ 800 ppm). Increase in plant spread in $\mathrm{T}_{7}$ and $\mathrm{T}_{6}$ might be due to growth promotive effect of $\mathrm{GA}_{3}$ resulting cell enlargement and cell elongation (Ei Shafe and Hassan, 1978) ${ }^{[7]}$ while minimum plant spread in $\mathrm{T}_{5}$ might be due to retardation of growth due to application of growth retardant like cycocel. Similar finding have been reported by Nair et al. (2002) ${ }^{[15]}$, Sujatha et al. (2002) ${ }^{[20]}$, Dalal et al. (2009) ${ }^{[5]}$ and Jamal et al. (2013) ${ }^{[10]}$ who proved that $\mathrm{GA}_{3} @ 100$ ppm/150 ppm increased plant spread in gerbera while application of growth retardant like ethrel reduced plant height in gerbera. Similar trends in change in plant spread was also observed in summer and rainy season.

\section{Number of leaves/plant}

The pooled data from both the year revealed that in winter season maximum number of leaves (34.84) were found in $\mathrm{T}_{8}$ receiving cycocel @ 700 ppm+ Amino Acid which was closely followed by $\mathrm{T}_{9}$ (Cycocel @ 800 ppm + Amino Acid), $\mathrm{T}_{4}$ (Cycocel @ 700 ppm) and $\mathrm{T}_{5}$ (Cycocel @ 800 ppm) while minimum number of leaves (24.63) were observed in $\mathrm{T}_{1}$ (Control). Increase in leaf number in $\mathrm{T}_{8}, \mathrm{~T}_{9}, \mathrm{~T}_{4}$ and $\mathrm{T}_{5}$ might be due to cycocel application with or without amino acid. When cycocel is applied in optimum concentration as in $\mathrm{T}_{8}$, it result dwarfness and bushiness of plants producing more number of leaves while least number of leaves in $\mathrm{T}_{1}$ (Control) was due to no application of no growth regulators. Similar finding of increased leaves number has been found in tuberose by dipping bulbs in cycocel @ 5000 ppm for 1 hour which was reported by Ganesh et al. (2013) ${ }^{[8]}$. Similar trends in change in leaves number was also observed in summer and rainy season.

\section{Leaf length}

Pooled data from both the years revealed that in winter season maximum leaf length $(35.65 \mathrm{~cm})$ was observed in $\mathrm{T}_{7}$ receiving GA @ 150 ppm + Amino acid which was at par with $\mathrm{T}_{6}$ (GA @ 100 ppm + Amino acid) and $\mathrm{T}_{3}$ (GA @ 150 $\mathrm{ppm})$. The minimum leaf length $(29.42 \mathrm{~cm})$ was found in $\mathrm{T}_{5}$ (cycocel @ 700 ppm). Increase in leaf length in $\mathrm{T}_{7}, \mathrm{~T}_{6}$ and $\mathrm{T}_{3}$ might be due to growth promotive effect of $\mathrm{GA}_{3}$ resulting cell enlargement and cell elongation (Eishafe and Hassan, 1978) [7]. Similar finding have been obtained by Cardoso et al. (2012) ${ }^{[3]}$, Patel et al. (2013) ${ }^{[16]}$ by application of gibberellin in gerbera.

The minimum leaf length recorded in $\mathrm{T}_{5}$ (cycocel @ 800 ppm) which might be due to application of growth retardant like like cycocel. Similar finding have been obtained by Lin (1991) with respect to application of growth retardant like ethrel in gerbera. Similar trends in change in leaf length was also observed in summer and rainy season.

\section{Leaf width}

In winter season the maximum leaf width $(11.69 \mathrm{~cm})$ was observed in $\mathrm{T}_{7}$ (GA @ 150 ppm + Amino Acid) which was at par with $\mathrm{T}_{6}$ (GA @ 150 ppm+ Amino Acid) followed by $\mathrm{T}_{3}$ (GA @ 150 ppm + Amino Acid) while minimum leaf width $(9.78 \mathrm{~cm})$ was observed in $\mathrm{T}_{5}$ (cycocel @ $\left.800 \mathrm{ppm}\right)$. The increase in leaf width might be due to growth promotive effect of Gibberellin i.e. cell elongation and cell expansion. Similar finding have been obtained by Dogra et al. (2012) ${ }^{[6]}$ with respect to application gibberellin @ 200 ppm in gerbera. The minimum leaf width in $\mathrm{T}_{5}$ might be due to retardation of growth due to cycocel application resulting small, reduced size leaves. Similar finding have been obtained by Kumar et al. (2008) ${ }^{[12]}$ who reported that application of growth retardant ethrel in gerbera reduced leaf width. Similar trends in change in leaf width was also observed in summer and rainy season.

\section{Length of petiole}

In winter season the maximum length of petiole $(9.95 \mathrm{~cm})$ was observed in $\mathrm{T}_{7}$ (GA @ $150 \mathrm{ppm}+$ Amino Acid) which was at par with $\mathrm{T}_{6}$ (GA @ 100 ppm+ amino acid) and $\mathrm{T}_{3}$ (GA @ 150 ppm) while minimum length of petiole $(7.49 \mathrm{~cm})$ was observed in $\mathrm{T}_{5}$ (cycocel @ 800 ppm). The increase in length of petiole might be due to growth promotive effect of $\mathrm{GA}_{3}$ like cell elongation resulting longer petiole while decrease in length of petiole might be due to application of cycocel. 
Similar finding have been obtained by Khan and Chaudhury (2006) ${ }^{[11]}$ with respect to application of gibberellin in gerbera Similar trends in change in length of petiole was also observed in summer and rainy season.

\section{Number of suckers/plant/month}

In winter season maximum number of suckers (3.33) were found in $\mathrm{T}_{8}$ which was closely followed by $\mathrm{T}_{9}$ (cycocel @ 800 ppm + amino acid) and $\mathrm{T}_{4}$ (cycocel @ 700 ppm) while minimum number of suckers (1.42) were found in $\mathrm{T}_{1}$ (control). The increase in number of suckers in $\mathrm{T}_{8}, \mathrm{~T}_{9}$ and $\mathrm{T}_{4}$ might be due to break of apical dominance and bushy nature of gerbera when applied with growth retardant like cycocel while lowest number of suckers in $\mathrm{T}_{4}$ might be due to no application of PBR. Similar trends in change in number of suckers/plant was also observed in summer and rainy season.

\section{Leaf Area}

In winter season maximum leaf area $\left(265.10 \mathrm{~cm}^{2}\right)$ was found in $\mathrm{T}_{7}$ (GA @ 150 ppm +amino acid) followed by $\mathrm{T}_{3}$ (GA @ $100 \mathrm{ppm})$ and minimum leaf area $\left(161.46 \mathrm{~cm}^{2}\right)$ was observed in $\mathrm{T}_{5}$ (cycocel @ $800 \mathrm{ppm}$ ). The increase in leaf area might be due to application of GA which help in cell expansion and cell elongation resulting increase in leaf area. Similar finding have been obtained by Nair et al. (2002) [15], Khan and Chaudhury (2006) ${ }^{[11]}$, Jamal et al. (2013) ${ }^{[10]}$ and Patel et al. (2013) [16] with respect to application of Gibberellin in gerbera. Decrease in leaf area in $\mathrm{T}_{5}$ might be due to application of growth retardant like cycocel. Growth retardant inhibit vegetative growth, cell elongation, cell enlargement thereby reducing leaf area. Similar trends in change in leaf area was also observed in summer and rainy season.

\section{Chlorophyll content}

In winter season maximum chlorophyll content (3.94 mg/leaf) was observed in $\mathrm{T}_{8}$ (cycocel @ 700 ppm + Amino acid) which was at par with $\mathrm{T}_{9}$ (cycocel @ 800 ppm + Amino Acid), $\mathrm{T}_{6}$ (GA@100 ppm + Amino Acid), T4 (cycocel @ 700 ppm) and $\mathrm{T}_{5}$ (cycocel @ 800 ppm). The minimum chlorophyll content $\left(3.06 \mathrm{mg} / \mathrm{g}\right.$ leaf) was observed in $\mathrm{T}_{1}$ (control). The increase in chlorophyll content in $\mathrm{T}_{8}, \mathrm{~T}_{9}, \mathrm{~T}_{4}$ and $\mathrm{T}_{5}$ might be due to application of growth retardant like cycocel. Growth retardant reduce vegetative growth, promote bushiness, compactness thereby increasing chlorophyll content per gram leaf. Similar finding have been obtained by Bekheta et al. (2008) ${ }^{[2]}$ with respect to application of growth retardant like paclobutrazole in gerbera. Besides, another treatment $\mathrm{T}_{6}(\mathrm{GA}$ @ 100 ppm + Amino acid) recorded chlorophyll content which was at par with cycocel treatment which corroborates with the finding of Jamal et al. (2013) ${ }^{[10]}$ with respect to GA application in gerbera and Sajid et al. (2015) ${ }^{[18]}$ with respect to application of GA in gladiolus. Gibberellin promote vegetative growth and increase chlorophyll content in leaf. The minimum chlorophyll content was found in $\mathrm{T}_{1}$ (control) where no growth regulator was applied. Similar trends in change in chlorophyll content was also observed in summer and rainy season.

\section{(B) Effect of PBR application on flowering parameters Number of flowers/plant $/ \mathrm{m}^{2} /$ season}

Pooled data from both the year revealed that in winter season maximum number of flowers/plant $/ \mathrm{m}^{2}$ (141.90) was found in $\mathrm{T}_{8}$ (Cycocel@ 900 ppm+ Amino Acid) which was closely followed by $\mathrm{T}_{4}$ (Cycocel @ 700 ppm) and $\mathrm{T}_{6}$ (GA @ 100ppm+ Amino Acid) while lowest number of flower (75.84) was observed in $\mathrm{T}_{1}$ (Control).

Increase in flower number in $\mathrm{T}_{8}$ and $\mathrm{T}_{4}$ may be due to application optimum concentration of Cycocel @ 700 ppm with or without amino acid. Being a growth retardant cycocel inhibits apical dominance and induce bushiness/ dwarfness which result in emergence of more number of suckers. When number of suckers increases, the number of flower/plant increases. Similar finding have been obtained by Mahamed (1992) ${ }^{[13]}$, Muthumanikam et al. (1999) ${ }^{[14]}$ and Kumar et al. (2008) [12] who reported increasing stalk thickness by application of growth retardant like ethrel in gerbera. Besides, Cycocel application another treatment $\mathrm{T}_{6}$ (GA @ 100 ppm+ Amino Acid) produced more number of flowers/plant which was very close to best treatment. Similar finding have been obtained by Sekar and Sujata (2001) ${ }^{[19]}$, Nair et al. (2002) ${ }^{[15],}$ Sujata et al. (2002), Dalal et al. (2009) ${ }^{[5]}$, Jamal et al. (2013) ${ }^{[10]}$ in increasing number of flowers/plant in gerbera. The minimum number of flower/plant obtained in $\mathrm{T}_{1}$ (Control) may be due to no application of growth regulator. Similar trends in change in flower number $/ \mathrm{m}^{2}$ was also observed in summer and rainy season.

Table 1: Impact of plant bio regulators on vegetative character i.e. Plant spread and Leaf number/plant (Pooled over years 2015-16 and 201617) in hybrid gerbera cv. Goliath\}

\begin{tabular}{|c|c|c|c|c|c|c|c|}
\hline \multirow{2}{*}{ Treatments No. } & \multirow{2}{*}{ Characters/Treatments } & \multicolumn{3}{|c|}{ Plant spread(cm) } & \multicolumn{3}{c|}{ Leaf number/plant } \\
\cline { 3 - 7 } & & Winter & Summer & Rainy & Winter & Summer & Rainy \\
\hline $\mathrm{T}_{1}$ & Control & 60.85 & 50.53 & 55.21 & 24.63 & 10.28 & 15.11 \\
\hline $\mathrm{T}_{2}$ & GA @ $100 \mathrm{ppm}$ & 64.25 & 55.96 & 57.64 & 30.42 & 13.98 & 19.46 \\
\hline $\mathrm{T}_{3}$ & GA @ 150 ppm & 66.05 & 58.45 & 60.06 & 28.79 & 12.48 & 17.67 \\
\hline $\mathrm{T}_{4}$ & Cycocel @ $700 \mathrm{ppm}$ & 59.09 & 47.34 & 52.64 & 33.52 & 17.15 & 25.40 \\
\hline $\mathrm{T}_{5}$ & Cycocel @ 800 ppm & 56.81 & 45.57 & 50.32 & 31.73 & 15.65 & 24.63 \\
\hline $\mathrm{T}_{6}$ & GA @ 100 ppm + AA & 67.07 & 58.66 & 59.99 & 32.38 & 15.63 & 23.32 \\
\hline $\mathrm{T}_{7}$ & GA @ 150 ppm + AA & 69.82 & 60.58 & 62.12 & 30.67 & 14.42 & 20.38 \\
\hline $\mathrm{T}_{8}$ & Cycocel @ 700 ppm + AA & 60.22 & 49.75 & 54.40 & 34.84 & 18.63 & 27.77 \\
\hline $\mathrm{T}_{9}$ & Cycocel @ 800 ppm + AA & 58.69 & 48.15 & 52.50 & 32.50 & 17.19 & 25.84 \\
\hline & SE (m) \pm & 0.730 & 2.201 & 0.663 & 0.352 & 0.247 & 0.656 \\
\hline & CD $(0.05)$ & 2.08 & 7.18 & 1.89 & 1.00 & 0.70 & 2.14 \\
\hline
\end{tabular}


Table 2: Impact of plant bio regulators on vegetative characters i.e. Leaf length and Leaf width (Pooled over years 2015-16 and 2016-17) in hybrid gerbera cv. Goliath

\begin{tabular}{|c|c|c|c|c|c|c|c|}
\hline \multirow{2}{*}{$\begin{array}{c}\text { Treatments } \\
\text { No. }\end{array}$} & \multirow{2}{*}{ Characters/Treatments } & \multicolumn{3}{|c|}{ Leaf length(cm) } & \multicolumn{3}{c|}{ Leaf width(cm) } \\
\cline { 3 - 8 } & Winter & Summer & Rainy & Winter & Summer & Rainy \\
\hline $\mathrm{T}_{1}$ & Control & 32.26 & 25.64 & 27.15 & 10.40 & 8.88 & 9.29 \\
\hline $\mathrm{T}_{2}$ & GA @ 100 ppm & 33.49 & 28.31 & 29.26 & 10.85 & 10.00 & 10.27 \\
\hline $\mathrm{T}_{3}$ & GA @ 150 ppm & 34.15 & 29.82 & 30.68 & 11.23 & 10.53 & 10.87 \\
\hline $\mathrm{T}_{4}$ & Cycocel @ 700 ppm & 30.69 & 23.80 & 25.73 & 10.06 & 8.38 & 8.70 \\
\hline $\mathrm{T}_{5}$ & Cycocel @ 800 ppm & 29.42 & 22.44 & 24.48 & 9.78 & 7.96 & 8.18 \\
\hline $\mathrm{T}_{6}$ & GA @ 100 ppm + AA & 34.89 & 29.57 & 30.71 & 11.27 & 10.69 & 10.97 \\
\hline $\mathrm{T}_{7}$ & GA @ 150 ppm + AA & 35.65 & 31.21 & 31.96 & 11.69 & 11.36 & 11.61 \\
\hline $\mathrm{T}_{8}$ & Cycocel @ 700 ppm + AA & 32.01 & 26.15 & 27.68 & 10.46 & 9.14 & 9.56 \\
\hline $\mathrm{T}_{9}$ & Cycocel @ 800 ppm + AA & 30.97 & 24.84 & 26.80 & 10.15 & 8.75 & 9.03 \\
\hline & SE (m) \pm & 0.422 & 0.809 & 0.907 & 0.136 & 0.401 & 0.284 \\
\hline & CD $(0.05)$ & 1.20 & 2.64 & 2.96 & 0.39 & 1.31 & 0.93 \\
\hline
\end{tabular}

Table 3: Impact of plant bio regulators on vegetative characters i.e. Length of petiole and Number of Suckers (Pooled over years $2015-16$ and 2016-17) in hybrid gerbera cv. Goliath

\begin{tabular}{|c|c|c|c|c|c|c|c|}
\hline $\begin{array}{c}\text { Treatments } \\
\text { No. }\end{array}$ & \multirow{2}{*}{ Characters/Treatments } & \multicolumn{2}{|c|}{ Length of petiole(cm) } & \multicolumn{3}{c|}{ Number of suckers/plant/month } \\
\cline { 3 - 8 } & Winter & Summer & Rainy & Winter & Summer & Rainy \\
\hline $\mathrm{T}_{1}$ & Control & 8.21 & 6.50 & 7.06 & 1.42 & 1.00 & 1.34 \\
\hline $\mathrm{T}_{2}$ & GA @ 100 ppm & 9.09 & 7.37 & 7.66 & 2.48 & 1.77 & 2.09 \\
\hline $\mathrm{T}_{3}$ & GA @ 150 ppm & 9.43 & 7.90 & 7.97 & 2.21 & 1.46 & 1.86 \\
\hline $\mathrm{T}_{4}$ & Cycocel @ 700 ppm & 7.90 & 5.97 & 6.58 & 2.94 & 2.13 & 2.84 \\
\hline $\mathrm{T}_{5}$ & Cycocel @ 800 ppm & 7.49 & 5.55 & 6.19 & 2.66 & 1.84 & 2.61 \\
\hline $\mathrm{T}_{6}$ & GA @ 100 ppm + AA & 9.56 & 8.02 & 8.32 & 2.69 & 1.94 & 2.38 \\
\hline $\mathrm{T}_{7}$ & GA @ 150 ppm + AA & 9.95 & 8.56 & 8.68 & 2.36 & 1.71 & 2.09 \\
\hline $\mathrm{T}_{8}$ & Cycocel @ 700 ppm + AA & 8.54 & 6.45 & 7.43 & 3.33 & 2.44 & 3.27 \\
\hline $\mathrm{T}_{9}$ & Cycocel @ 800 ppm + AA & 8.23 & 6.08 & 6.83 & 2.94 & 2.09 & 2.86 \\
\hline & SE (m) \pm & 0.219 & 0.384 & 0.119 & 0.206 & 0.069 & 0.076 \\
\hline & $\mathrm{CD}(0.05)$ & 0.71 & 1.25 & 0.39 & 0.67 & 0.20 & 0.22 \\
\hline
\end{tabular}

Table 4: Impact of plant bio regulators on vegetative characters i.e. Leaf area and Chlorophyll content (mg/g leaf) (Pooled over years 2015-16 and 2016-17) in hybrid gerbera cv. Goliath

\begin{tabular}{|c|c|c|c|c|c|c|c|c|c|c|}
\hline \multirow{2}{*}{$\begin{array}{l}\text { Treatments } \\
\text { No. }\end{array}$} & \multirow{2}{*}{ Characters/Treatments } & \multicolumn{3}{|c|}{ Leaf $\operatorname{area}\left(\mathrm{m}^{2}\right)$} & \multicolumn{3}{|c|}{ Chlorophyll content(mg/g leaf) } & \multicolumn{3}{|c|}{ Number of flowers/plant/m² } \\
\hline & & Winter: & Summer & Rainy & Winter & Summer & Rainy & Winter & Summer & Rainy \\
\hline $\mathrm{T}_{1}$ & Control & 178.57 & 101.05 & 164.20 & 3.06 & 1.87 & 1.90 & 75.84 & 50.34 & 62.34 \\
\hline $\mathrm{T}_{2}$ & GA@100 ppm & 204.84 & 118.43 & 177.15 & 3.68 & 2.61 & 3.12 & 118.56 & 78.78 & 92.28 \\
\hline $\mathrm{T}_{3}$ & GA @ $150 \mathrm{ppm}$ & 228.33 & 130.06 & 187.91 & 3.41 & 2.30 & 3.04 & 105.12 & 68.34 & 79.62 \\
\hline $\mathrm{T}_{4}$ & Cycocel @ 700 ppm & $\mid 167.55$ & 93.64 & 160.08 & 3.82 & 2.74 & 3.26 & 133.56 & 95.34 & 109.56 \\
\hline $\mathrm{T}_{5}$ & Cycocel@800 ppm & 161.46 & 86.03 & 152.62 & 3.70 & 2.64 & 3.17 & 114.18 & 85.56 & 96.84 \\
\hline $\mathrm{T}_{6}$ & GA @ 100 ppm + AA & 213.54 & 129.41 & 188.44 & 3.89 & 2.72 & 3.21 & 130.56 & 90.12 & 100.62 \\
\hline $\mathrm{T}_{7}$ & GA @150 ppm & 265.10 & 139.68 & 201.28 & 3.44 & 2.54 & 3.15 & 119.34 & 81.84 & 89.28 \\
\hline $\mathrm{T}_{8}$ & Cycocel @ 700 ppm + AA & 196.22 & 102.31 & 173.63 & 3.94 & 2.91 & 3.39 & 141.90 & 108.84 & 118.56 \\
\hline $\mathrm{T}_{9}$ & Cycocel @800 ppm + AA & 171.99 & 95.53 & 170.43 & 3.89 & 2.79 & 3.31 & 128.28 & 93.90 & 109.62 \\
\hline & $\mathrm{SE}(\mathrm{m}) \pm$ & 11.551 & 5.763 & 3.295 & 0.143 & 0.084 & 0.038 & 3.680 & 2.508 & 2.155 \\
\hline & $\mathrm{CD}(0.05)$ & 37.66 & 18.79 & 9.39 & 0.47 & 0.24 & 0.21 & 12.00 & 7.15 & 6.14 \\
\hline
\end{tabular}

\section{Conclusion}

From the above investigation it can be concluded that application of $\mathrm{GA}_{3} @ 150$ ppm with amino acid recorded maximum plant spread, length of leaf, leaf width, length of petiole and leaf area while maximum number of suckers/plant, maximum chlorophyll content and maximum number of flowers/plant was found in cycocel @ 700 ppm + Amino acid. The result will be torch bearer for the researcher as well as gerbera grower for enhancing quality and flower production under open field condition.

\section{References}

1. Bose TK, Yadav LP, Pal P, Parthasarathy VP, Das P. Commercial flowers, $2^{\text {nd }}$ Edition, Naya Udyog, Calcutta, India, 2003.

2. Bekheta MA, Abbas SEL, Kobisy OS, Mahgoub MH. Influence of selenium and paclobutrazole on growth, metabolic activities and Anatomical characters of
Gerbera. Australian Journal of Basic and applied Science, 2008; 2(4):1284-1297.

3. Cardoso JC, Ono EO, Rodrigues JD. Gibberllic acid in vegetative and reproductive development of Phalaenopsis orchid hybrid genus. Horticultura Brasileria. 2012; 30:7174.

4. Chauhan N. Performance of gerbera genotype under protected cultivation. Department of Horticulture, College of Agriculture, Dharwad. University of Agriculture Science, Dharwad, 2005.

5. Dalal SR, Somavanshi AV, Karale GD. Effect of gibberellic acid on growth, flowering, yield and quality of gerbera under polyhouse conditions. International Journal of Agricultural Sciences. 2009; 5(2):355-356.

6. Dogra S, Pandey RK, Bhat DJ. Influence of gibberelic acid and plant geometry on growth, flowering, production in gerbera under Jammu agroclimate. International 
Journal of Pharma and Bio Sciences. 2012; 3(4):10831090.

7. Ei-shafe T, Hassan A. Effect of gibberllic acid on growth, flowering, yield and quality of gerbera under polyhouse conditions. International Journal of Agricultural Sciences. 1978; 37(2):25-39.

8. Ganesh S, Soorianath Sundaram K, Kanan M. Studies on effect of plant growth regulators and micronutrients on growth, floral characters and yield of tuberose (Polyanthes tuberosa L.) cv. Prajwal. Asian Journal of Horticulture. 2013; 8(2):696-700.

9. Gomez KA, Gomez AA. Statistical procedure for agricultural research. John Willeyl Sons Inc., New York, 1984, 1-680.

10. Jamal uddin AFM, Mehraj $\mathrm{H}$, Taufique $\mathrm{T}$, Ona AF, Parvin S. Foliar Application of Gibberllic Acid on Growth and Flowering of Gerbera Cultivars. Journal of Bioscience and Agriculture Research, 2014; 2(1):52-58.

11. Khan AS, Chaudhry NY. GA 3 improves flower yield in some cucurbits treated with lead and mercury. African Journal of Biotechnology. 2006; 5:149-153.

12. Kumar NP, Reddy YN, Chandra Shekar R. Effect of growth regulators on flowering, production in gerbera. Indian Journal of Horticulture. 2008; 65 (1)73-78.

13. Mohamed SM. Influence of some growth regulators on growth and flowering of gerbera. Journal of Applied Science. 1992; 7:653-667.

14. Muthu Kumar S, Ponnuswami V, Jawaharlal M, Ramesh Kumar A. Effect of plant growth regulators on growth, yield and exportable quality of cut roses. The Bioscan. 2012; 7(4):733-738.

15. Nair SA, Sujatha K, Medhi RP. Performance of gerbera cultivars in Bay Island. Indian Journal of Horticulture. 2002; 59(8):322-325.

16. Patel BB, Desai JR, Patel GD, Patel HF. Influence foliar application of nitrogen and plant growth regulators on growth, flowering of gerbera. Bioinfolet Journal. 2013; 10(2A):415-417.

17. Patra SK, Beura S, Sashani T. Efficacy of $\mathrm{GA}_{3}$ on growth and flowering regulation of in vitro raised hybrid gerbera under shade net. Agri. Sci. Digest. 2015; 35(3):173-177.

18. Sajid M, Anjum MA, Hussain S. Foliar application of plant growth regulators affects growth, flowering, vase life and corm production of Gladiolus. Bulgerian Journal of Agricultural Science. 2015; 21(5):982-989.

19. Sekar K, Sujata A. Effect of growing media and $\mathrm{GA}_{3}$ on growth and yield of flower of gerbera (Gerbera jamesonii B.) under naturally ventilated green house. South Indian Horticulture. 2001; 49(special):338-341.

20. Sujatha K, Gowda JVN, Khan MM. Effect of different fertigation level on gerbera under low cost greenhouse. Journal of Ornamental Horticulture. 2002; 5(1):54-59. 